\title{
Composition and structure of a lowland forest in the Core Zone of the Bukit Duabelas National Park, Jambi, Indonesia
}

\author{
Azwar Anas ${ }^{1}$, Kuswata Kartawinata $^{2}$, and Nisyawati ${ }^{3}$ \\ ${ }^{1}$ SMA Negeri 15 Bungo, Jalan Punai Tuo Limbur, Kecamatan Limbur Lubuk Mengkuang, Kabupaten Bungo, Jambi \\ 37213, Indonesia \\ ${ }^{2}$ Integrative Research Center, The Field Museum of Natural History, 1400 Lake Shore Drive, Chicago, IL 60605, USA \\ ${ }^{3}$ Departemen Biologi, Fakultas Matematika dan Ilmu Pengetahuan Alam, Universitas Indonesia, Gedung E Lantai 2 , \\ Kampus UI, Depok 16424, Indonesia
}

Corresponding author: Kuswata Kartawinata, kkartawinata@gmail.com

\begin{abstract}
The objective of the study was to obtain data on composition and structure of the forest in the midsection of the Bukit Duabelas National Park core zone, designed to complement the existing data and provide new information potentials for the management of the park core zone. The study was carried out in October-November 2012. Observations were made on plots of one hectare $(100 \mathrm{~m} \times 100 \mathrm{~m})$, which was divided into 100 subplot, measuring $10 \mathrm{~m} \times 10 \mathrm{~m}$ each. Enumeration of tree species with diameters $\geq 10 \mathrm{~cm}$ revealed that as many as 540 individuals were recorded, consisting of 89 species and 36 families, with a total basal area of $30.837 \mathrm{~m}^{2}$ and only three species of Dipterocarpaceae were registered. The forest had a low diversity as indicated by low species richness, much lower than in the undisturbed lowland primary forests in the Batang Gadis National Park in North Sumatra, where similarity was very low (5.9\%). The forest in the plot was designated as the Dacryodes rostrata- Shorea leprosula Association, named after two species with highest importance values, thus the dominant. The structure and species composition pointed to the regenerating forest after heavy disturbances. The forest has been undergoing slow natural succession, leading to the formation of the forest similar to the original climax forest. Natural recovery through succession could be enhanced and assisted by means of ecological restoration, through planting of tree species characteristics of forests in Jambi, including species of Dipterocapaceae, useful species having values to maintain the livelihood of the indigenous native tribe Suku Anak Dalam and rare, endemic other species having high conservation values.
\end{abstract}

\begin{abstract}
ABSTRAK
Tujuan studi ini adalah untuk memperoleh data tentang komposisi dan struktur hutan di bagian tengah zona inti Taman Nasional Bukit Duabelas. Studi dirancang untuk melengkapi data yang telah ada dan untuk menyajikan informasi baru yang berpotensi untuk digunakan dalam pengelolaan zona inti taman nasional. Penelitian dilaksanakan pada bulan Oktober-November 2012 dalam petak seluas satu hektare (100 m x 100 m), yang dibagi menjadi 100 anak-petak dengan ukuran masing-masing $10 \mathrm{~m}$ x $10 \mathrm{~m}$. Pencacahan pohon dengan diameter $\geq 10 \mathrm{~cm}$ menghasilkan 540 batang, yang terdiri atas 89 jenis dan 36 suku, dengan luas bidang dasar total $30.837 \mathrm{~m}^{2}$ dan hanya tercatat tiga jenis Dipterocarpaceae. Keanekaragaman jenis hutan rendah, seperti ditunjukan oleh rendahnya kekayaan jenis, jauh lebih rendah dibandingkan dengan hutan primer yang tidak terganggu di Taman Nasional Batang Gadis di Sumatra Utara, yang mempunyai kesamaan hanya 5,9 \% dengan Taman Nasional Bukit Duabelas. Berdasarkan dua jenis dominan dengan nilai kepentingan tinggi, komunitas pohon dalam petak dinamakan Asosiasi Dacryodes rostrata- Shorea leprosula. Struktur dan komposisi jenis menunjukan status hutan sebagai hutan yang sedang beregenerasi setelah mengalami gangguan. Hutan sedang mengalami suksesi alami yang lambat menuju ke pembentukan hutan yang serupa dengan hutan klimaks aslinya. Pemulihan alami melalui suksesi dapat dipercepat dan dibantu dengan restorasi ekologi melalui penanaman jenis-jenis khas hutan alami Jambi, termasuk Dipterocapaceae, jenis-jenis bermanfaat dan mempunyai nilai untuk keberlanjutan kehidupan dan kesejahteraan masyarakat asli Suku Anak Dalam dan jenis-jenis langka, endemik dan jenis lain yang mempunyai nilai konservasi tinggi.
\end{abstract}

Keywords: Association, disturbances, regenerating forest, ecological restoration, species richness, structure and composition

\section{INTRODUGTION}

The lowland rain forests of Sumatra constitute an important center of plant species diversity and the hub of the geography of plant families and genera within the Malesian region (Steenis 1950; Whitmore, 1986; Kartawinata, 2013). The Bukit Duabelas National Park (BDNP) contains a fraction of these lowland

Submitted 08 January 2021; Accepted 10 March 2021. rain forests (Sylviani, 2008; Setiawan, 2010) and constitutes an important biodiversity center in the middle section of Sumatra [BAPPENAS (Badan Perencanaan Pembangunan Nasional), 2003]. Much of the lowland rain forests of Sumatra, dominated by dipterocarp species, have experienced destructive and extensive commercial logging, leaving only undisturbed remnants of forets as scattered mosaics in the 
lowlands. The Bukit Dua Belas National Partk is also a catchment area for the Batanghari River, one of the largest rivers in Jambi (Wiriadinata \& Setyowati, 2000; Setiawan, 2010. It is a uniqe protected area in view of the fact that it is the last home of the ethnic Suku Anak Dalam (SAD) or known also as orang rimba (Wiriadinata \& Setyowati 2000; Setyowati, 2003; Sriyanto et al. 2003).

Conservation and management of forests within protected areas, including BDNP, require a good and correct planning. In this respect optimal and sustainable management of forest resousrces can be implemented well if accurate, complete and up-to-date data and information on vegetation were available. They should provide a representation of current condition of plant communities. which constitute the habitats to support the survival of numerous other organisms living in the BDNP areas.

A better knowledge on detailed description of strructure, composition and ecology of lowand rain forests of Sumatra, required for better sustainable development and conservation, are relatively limited. Data and information on the vegetation and physiography of Sumatra have been summarised by Laumonier (1997). Scattered studies on vegetation, primarily forests, have been conducted in various parts of Sumatra, mainly in the national parks and other protected areas. They include those in the Batang Gadis National Park (Kartawinata et al., 2004), Berbak National Park (Silvius et al.,1984), Gunung Leuser National Park (Abdulhadi, 1991; Samsoedin and Heriyanto, 2010), Harapan Tropical Rain Forest (Mansur et al. 2010), Hutan Adat Imbo Mengakadai (Elviqar, 2013; Hermawan, 2013), Hutan Danau Bangko (Polosakan, 2011), Kerinci Seblat National Park (Gillisosn et al., 1996), Rimbo Panti Nature Reserve (Yusuf et al., 2005), Tesso Nilo National Park (Gillison, 2001). Studies on the structure and species composition in the eastern and western sections of the BDNP core zone, respectively were undertaken by Rahmah et al. (2016) and Sehati (2013).

The present phytososciological study in the midsection of the BDNP core zone was designed to complement the existing data and provide new information on the species composition, structure and the potentials of the forest in the BDNP core zone. They can be used as a scientific basis and reference for better execution of conservation and management of the park.

\section{METHODS}

The BDNP was established by the Decree of the Ministry of Forestry and Plantation (No. 258/Kpts-II/2000 dated 23 August 2000). It had a total area of 60.500 hectare, consisting of primary and secondary forests, which were converted from the permanent production forests, limited production forests and forest designated for other uses (Sriyanto et al., 2003). The entire park was located within the lowland dipterocarp forest region of Sumatra (Lamounier, 1997; Whitmore, 1986).

Many important useful plants could be found in BDNP, including fruit trees such as durian (Durio spp.), important hard wood producing bulian (Eusideroxylon zwageri), latex producing tree species (Dyera costulata) and rattan producing palms such as rotan manau (Calamus manan) and jernang (Daemonorops draco). To date 41 species of orchids. 107 species of flowering plant and 27 species of fungi have been recorded to have medicinal values (Kementerian Kehutanan dan Balai TNBD, 2011). The Bukit Duabelas National Park (BDNP) contained also rare plant species, including Eusideroxylon zwageri, Fagraea fragrans, Calamus manan, Daemonorops draco and Dyera costulata (Kementerian Kehutanan dan Balai TNBD, 2011; Rahmah et al., 2016)

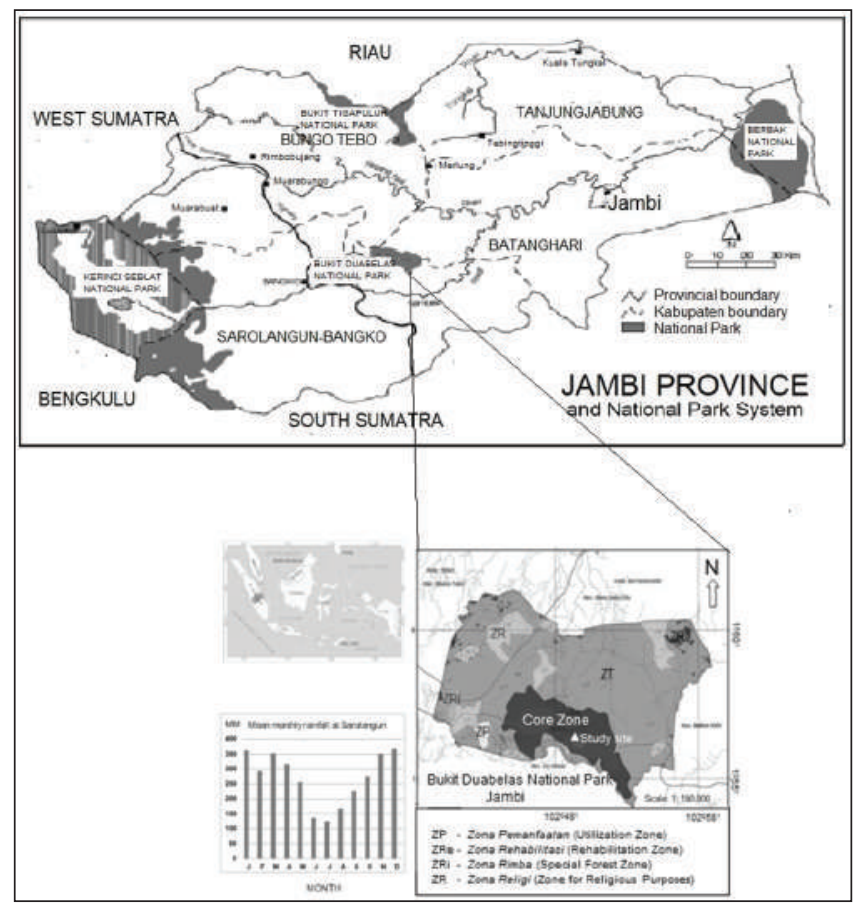

Figure 1. The map showing the geographic location and the mean monthly rainfall of the study site in the midsection of the core zone of the Bukit Duabelas National Park within the National Park System of the Jambi Province (After Rahmah et al., 2016 \& Kementerian Kehutanan dan Balai TNBD, 2011; with modification)

The map of BDNP (Figure 1) shows the park geographic location at the $102^{0} 31^{\prime} 37^{\prime \prime}-102^{\circ} 48^{\prime} 27^{\prime \prime}$ East and $01^{\circ} 44^{\prime} 35^{\prime \prime}-02^{\circ} 03^{\prime} 15^{\prime \prime}$ South. The topography ranged from undulating to hilly, with the altitude of 260-400 masl (meter above sea level). The Red Yellow Podsolic soil was dominant in the area (Kementerian Kehutanan dan Balai TNBD, 2011). The 38-year record of the mean annual rainfall (Berlage, 1949) was $3224 \mathrm{~mm}$. The highest mean monthly rainfall of 392.9 $\mathrm{mm}$ was recorded in November and the lowest of $27.1 \mathrm{~mm}$ in August and $52.7 \mathrm{~mm}$ in September [BPS 
(Badan Pusat Statistik) Kabupaten Sarolangun, 2015]. The temperature range in the area was $23-30{ }^{\circ} \mathrm{C}$ and the humidity range was $80-94 \%$ (Kementerian Kehutanan dan Balai TNBD, 2011).

Specifically the sampling was undertaken in the forest at the midsection of the core zone of the park using the plot method (Cox 1967; Mueller-Dombois \& Ellenberg1972, 2016), with the plot size of one-hectare. Habitat conditions, including plot position, mean elevation, topography, gaps and tree crown coverage, soils, presence of litters, $\mathrm{pH}$ and air humidity were recorded. The mean elevation of the plot was measured by the method of Harms et al. (2001).

The one hectare plot $(100 \mathrm{~m} \times 100 \mathrm{~m})$ was divided into 100 subplots of $10 \mathrm{~m} \times 10 \mathrm{~m}$ each (Kartawinata et al., 2004; Samsoedin \& Heriyanto, 2010; Rahmah et al, 2016). All tree species with DBH [Diameter at Breast Height at the height of $1.30 \mathrm{~m}$ (Kartawinata et al., 2004; Purwaningsih \& Yusuf, 2005; Heriyanto et al., 2019)] $\geq 10 \mathrm{~cm}$ were recorded. The records included name of species, number of trees, stem diameter (diameters of trees with buttresses were measured 20 $\mathrm{cm}$ above the buttresses), tree height, bole height to the first branch (Mueller-Dombois \& Ellenberg, 1974, 2016) and tree position using the GPS (Global Positioning System). The subplots and the plot were made permanent, in which every tree with a $\mathrm{DBH} \geq$ $10 \mathrm{~m}$ was numbered and labelled using an alluminum plate nailed to the stem $10 \mathrm{~cm}$ above the line of the diameter measurement.

Preliminary identification of species was undertaken in the field using available published keys, including guide to identifiction of dipterocarp trees of Sumatra (Newman et al.,1999). Voucher specimens of trees within the plot were collected and further identified and confirmed at the Herbarium Bogoriense, Center for Biological Research, LIPI at Cibinong, Bogor.

All collected data were tabulated and analysed to determine Density (D), Relative Density (RD), Frequency (F), Relative Frequency (RF), Dominance (Do), Relative Dominance (RDo), and Importance Value (IV) [Cox, 1967; Mueller-Dombois \& Ellenberg, 1974, 2016]. The standard method (Mueller-Dombois \& Ellenberg. 1974, 2016; Rahmah et al., 2016; Purwaningsih et al., 2017) was applied to calculate density frequency and dominance. Density was defined as the number of individuals per unit area. In the present study we were dealing with trees, hence the density per species was calculated by the number of trees of each species in the plot of one hectare. The density in the plot was the sum of the trees of all species and was presented as the number of trees per hectare. The Relative Density (RD) for each species was then computed as follows:

$$
\mathrm{RD}=\frac{\text { number } \text { of trees of a species }}{\text { total number of trees }} \times 100 \%
$$

Frequency was expressed as the number of occurrences of a species in subplots within the plot and was computed as the percentage of the total number of subplots. Relative Frequency (RF) was expresed as follows:

$$
\mathrm{RF}=\frac{\text { frequency of a species }}{\text { sum offrequency of all species }} \times 100 \%
$$

The dominance (Do) was determined by the stem cover, which was expressed as basal area (BA). BA was calculated with the formula of $\mathrm{BA}=(1 / 2 \mathrm{~d}) 2 \pi$, where $\mathrm{d}$ stands for diameter. The dominance of a species was obtained by totalling the BA values for all trees in the species. The Relative Dominance (RDo) was then computed with following formula:

$$
\mathrm{RDo}=\frac{\text { dominance of a species }}{\text { dominance of all species }} \times 100 \%
$$

The Importance Value (IV) of a species was calculated by summing up RD, RF and RDo in the plot, thus:

$$
\mathrm{IV}=\mathrm{RD}+\mathrm{RF}+\mathrm{RDo}
$$

The Family Important Value (FIV) was computed by totaling the Importance Values of all species in a family (Kartawinata et al., 2004).

\section{RESULTS}

\section{Composition}

Appendix 1 shows that in 100 subplots making up the one-hectare plot, we recorded 540 individual trees, comprising 89 species and 36 families with the total basal area (BA) of $30.837 \mathrm{~m}^{2} / \mathrm{ha}$. The authors of the scientific names in the present study are attached to all species listed in Appendix 1. The characteristics of the composition and structure of the forest is summarised in Table 1, which shows that Dipterocarpaceae was not dominant, consisting only of Shorea leprosula, Parashorea lucida and Parashorea sp. (Appendix 1).

Appendix 1 indicates that most of species had low values of density $(\mathrm{D})$, dominance expressed as basal area $(\mathrm{BA})$, frequency $(\mathrm{F})$ and importance value (IV). It shows that 10 species had high IV, where two of them had the highest IV, that were Dacryodes rostrata (IV= 15.80) and Shorea leprosula $(\mathrm{IV}=15.58)$. They constituted the dominant and co-dominant species and on the basis of this dominance (Mueller Dombois \& Ellenberg, 1974, 2016) the tree community in the forest of the midsection of BDNP core zone could be designated as the Dacryodes rostrata- Shorea leprosula Association. Other eight prevalent species with IV $>10$ (Appendix 1), that characterized the association were Hydnocarpus sp. (IV=14.91), Antidesma neurocarpum (IV=14.30); Dialium platysepalum $\quad(\mathrm{IV}=12.67), \quad$ Artocarpus odoratissimus (IV=10.83), Dacryodes rugosa (IV=10.17), Parashorea 
lucida (IV=10.11), Mussaenda frondosa $(\mathrm{IV}=9.33)$ and Symplocos sp. (IV=9.03).

Dacryodes rostrata had the highest density (32 trees/ha), followed by Hydnocarpus sp. and Antidesma neurocarpum (Figure 2a), while the lowest tree density occured in 30 species with Dacryodes rostrata density of one tree peer hectare (Appendix 1). The highest frequency was recorded in Dacryodes rostrata followed by Antidesma neurocarpum and Hydnocarpus sp. (Figure 2b). In terms of basal area Appendix 1 shows that three species had the highest values, they were Shorea leprosula $\left(2.83 \mathrm{~m}^{2}\right)$, Dialium platysepalum $\left(2.58 \mathrm{~m}^{2}\right)$ and Artocarpus odoratissimus $\left(1.84 \mathrm{~m}^{2}\right)$.

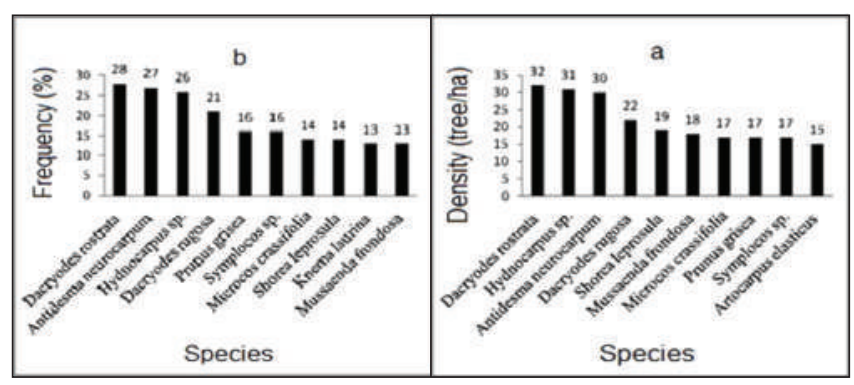

Figure 2. (a) Ten tree species with highest density (trees/ha) and (b) ten tree species with highest frequency in the forest of the mid section of the BDNP core zone.

Among the 89 tree species present in the plot, 10 species having IV $>10$ jointly dominated the forest, where as mentioned above Dacryodes rostrata was the primary species with highest IV of 15.80 (Appendix 1). The highest IV was atributed to high density and high frequency, implying that its mean tree diameter was small $(20.02 \mathrm{~cm})$. It was smaller compared to diameters of Dialium platysepalum $(45.17 \mathrm{~cm})$, Shorea leprosula $(38.20 \mathrm{~cm})$, Parashorea lucida $(37.08 \mathrm{~cm})$ and Artocarpus odoratissimus $(36.74 \mathrm{~cm})$. To the contrary Diallium platysepalum, Shorea leprosula, Parashorea lucida and Artocarpus odoratissimus. which were included in the 10 dominant species were observed to have a relatively lower density and frequency compared to that of Dacryodes rostrata.

Table 1. Characteristics of the composition and structure of the forest in a one hectare plot at the midsection of the BNDP core zone, Jambi.

\begin{tabular}{|l|c|c|c|}
\hline Forest characteristics & Dipterocarpaceae & $\begin{array}{c}\text { Non } \\
\text { Dipterocarpaceae }\end{array}$ & Total \\
\hline Number of species & $3(3.37 \%)$ & $85(96.63 \%)$ & 88 \\
\hline Density (Trees/ha) & $36(6.67 \%)$ & $504(93.33 \%)$ & 540 \\
\hline Basal Area $\left(\mathrm{m}^{2}\right)$ & $5.01(16.25 \%)$ & $25.827(83.75 \%)$ & 30.837 \\
\hline Importance Value & $28.89(9.63 \%)$ & $271.11(90.37 \%)$ & 300 \\
\hline
\end{tabular}

Figure 3 demonstrates the species-area curve expressing the pattern of tree species richness in subplots. It shows that the number of species increased as the area extended and there was no indication of the curve to flatten, implying that the one-hectare area did not represent the minimal area. This is comparable to the phenomenon in the primary lowland forests of
Sumatra and Kalimantan (Kartawinata et al., 2004; Kartawinata et al., 2008).

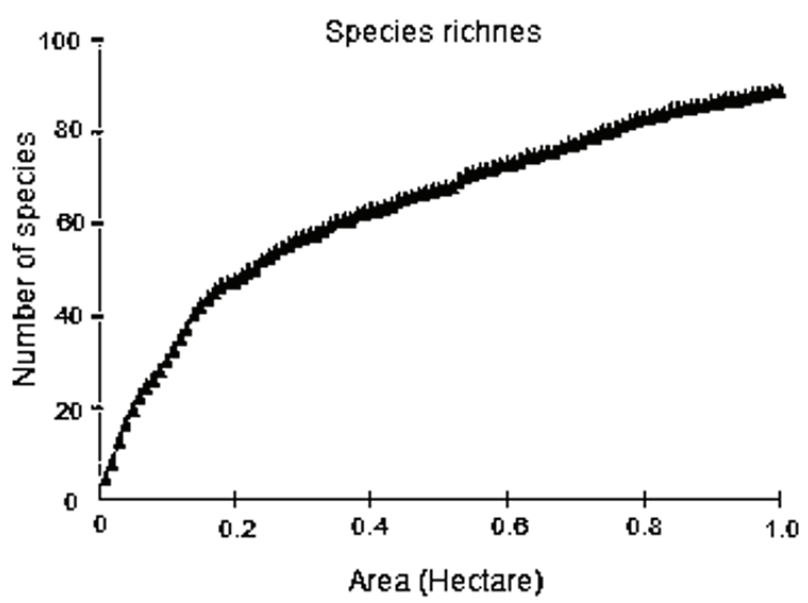

Figure 3. Species-area curve of tree species with $\mathrm{DBH} \geq 10$ $\mathrm{cm}$ in 100 subplots of the $100 \mathrm{~m} \times 100 \mathrm{~m}$ plot in the forest of the midsection of BDNP core zone.

In this study we recorded 36 families and 20 of them had highest IV (Table 2). They were families commonly found in the lowland forests of Sumatra, including Burseraceae. Dipterocarpaceae, Rubiaceae, Lauraceae and Euphorbiaceae (Anwar et al., 1984). Lauraceae contained the highest number of species. It is the family characterizing the lowland forests of Southeast Asia (Yamada, 1976), including Kalimantan (Kartawinata et al., 2008). The other families with high species number were Euphorbiaceae and Malvaceae.

Euphorbiaceae and Phyllanthaceae commonly occurred in both primary and secondary lowland forests (Kartawinata et al., 2004). The species of these families have an adaptive capability to grow in the open areas, including gaps in primary forests (Whitmore, 1986). In the mean time 14 families $(39 \%)$ contained one species each. Dipterocarpaceae (Table 1) was represented by only three species (Parashorea lucida, Parashorea sp. and Shorea leprosula) with the total basal area of $5.01 \mathrm{~m} 2$ or $16.25 \%$ of the total (Table 1).

Table 1 shows that the total BA in the plot was $30.837 \mathrm{~m}^{2}$ representing 540 trees with the mean BA of $0.057 \mathrm{~m}^{2}$. Table 3 indicates that the soil surface of the one-hectare plot in the mid-section of the core zone of BDNP was mostly covered by 10 species having highest BA totalling $15.515 \mathrm{~m}^{2}$ or $50.31 \%$ of the total BA. The pecies of Dipterocarpaceae having the highest BA was represented by Shorea leprosula with BA of $2.829 \mathrm{~m}^{2}$ and Parashorea lucida with BA of $1.795 \mathrm{~m}^{2}$ or $14.99 \%$ of the total BA, comparable to the values elsewhere in Sumatra (Kartawinata et al., 2004) and Kalimantan (Kartawinata et al, 2008). Another dipoterocarp species, Parashorea sp. had only an insignificant BA $\left(0.38 \mathrm{~m}^{2}\right)$. 
Table 2. Ten families with highest number of tree species with $\mathrm{DBH} \geq 10 \mathrm{~cm}$ and highest IV in the one-hectare lowland forest plot at the mid-section of the BDNP core zone, Jambi.

\begin{tabular}{|c|c|c|c|c|c|}
\hline \multirow{2}{*}{ Family } & \multicolumn{2}{|c|}{ Species } & \multirow{2}{*}{ Family } & \multicolumn{2}{|c|}{ IV } \\
\hline & Number & $\%$ & & Number & $\%$ \\
\hline Lauraceae & 6 & 6.74 & Burseraceae & 31.60 & 10.53 \\
\hline Euphorbiaceae & 5 & 5.62 & Dipterocarpaceae & 28.89 & 9.63 \\
\hline Malvaceae & 5 & 5.62 & Phyllanthaceae & 23.38 & 7.79 \\
\hline Clusiaceae & 4 & 4.49 & Moraceae & 22.37 & 7.46 \\
\hline Moraceae & 4 & 4.49 & Flacourtiaceae & 20.21 & 6.74 \\
\hline Myristicaceae & 4 & 4.49 & Fabaceae & 16.32 & 5.44 \\
\hline Olacaceae & 4 & 4.49 & Lauraceae & 13.89 & 4.63 \\
\hline Phyllanthaceae & 4 & 4.49 & Rubiaceae & 12.85 & 4.28 \\
\hline Rubiaceae & 4 & 4.49 & Euphorbiaceae & 11.94 & 3.98 \\
\hline Sapotaceae & 4 & 4.49 & Malvaceae & 10.06 & 3.35 \\
\hline Total & 44 & 49.44 & Total & 191.51 & 63.84 \\
\hline Other 26 & 45 & 50.56 & Other 26 & 108.49 & 36.16 \\
\hline
\end{tabular}

Table 3. Desending Basal Area (BA) of ten tree species with $\mathrm{DBH} \geq 10 \mathrm{~cm}$ in the one-hectare lowland forest plot at the mid-section of the BDNP core zone, Jambi.

\begin{tabular}{|c|l|l|c|}
\hline No & Species & Family & $\mathrm{BA}\left(\mathrm{m}^{2}\right)$ \\
\hline 1 & Shorea leprosula & Dipterocarpaceae & 2.829 \\
\hline 2 & Dialium platysepalum & Fabaceae & 2.580 \\
\hline 3 & Artocarpus odoratissimus & Moraceae & 1.840 \\
\hline 4 & Parashorea lucida & Dipterocarpaceae & 1.795 \\
\hline 5 & Dacryodes rostrata & Burseraceae & 1.261 \\
\hline 6 & Hydnocarpus sp. & Flacourtiaceae & 1.235 \\
\hline 7 & Baccaurea macrophylla & Phyllanthaceae & 1.031 \\
\hline 8 & Mussaenda frondosa & Rubiaceae & 1.021 \\
\hline 9 & Antidesma neurocarpum & Phyllanthaceae & 0.978 \\
\hline 10 & Artocarpus elasticus & Moraceae & 0.945 \\
\hline Total & & & $15.515 \mathrm{~m}^{2}(50.31 \%)$ \\
\hline 79 other species & & $15.322 \mathrm{~m}^{2}(49.69 \%)$ \\
\hline Total & & & $30.837 \mathrm{~m}^{2}(100 \%)$ \\
\hline
\end{tabular}

\section{STRUGTURE}

The stucture of a forest is reflected by the horizontal and vertical ditribution. Horizontal distribution is generally expressed in terms of diameter class distribution (Purwaningsih \& Yusuf, 2005) and vertical distribution by height stratification of tree crowns ((Richards, 1996; Mirmanto, 2009).

It is always the case and is a feature of a primary tropical forest that a diameter class distribution curve forms an inverted $\mathrm{J}$ shape, where the tree diameters $<$ $20 \mathrm{~cm}$ are dominant in the population, reflecting general characteristics of dynamic tropical rain forest (Richards, 1996). In the present plot the trees with DBH $<20 \mathrm{~cm}$ amounted to 292 trees or $54.07 \%$ (Figure 4) .
Table 4 shows the diameter class distribution of the 10 tree species with highest IV. Dacryodes rostrata was dominant at the $10-19.9 \mathrm{~cm}$ diameter class. It should be noted also that the ten species were well represented in the $10.9-19.9 \mathrm{~cm}$ and $30-30.9 \mathrm{~cm}$ diameter classes. The number of species decreased as the diameter increased. At the upper end of diameter class of 90-90.9 cm we recorded only two species, that were Dialium platysepalum and Parashorea lucida, while Shorea leprosula was present at $80-89.9 \mathrm{~cm}$. 


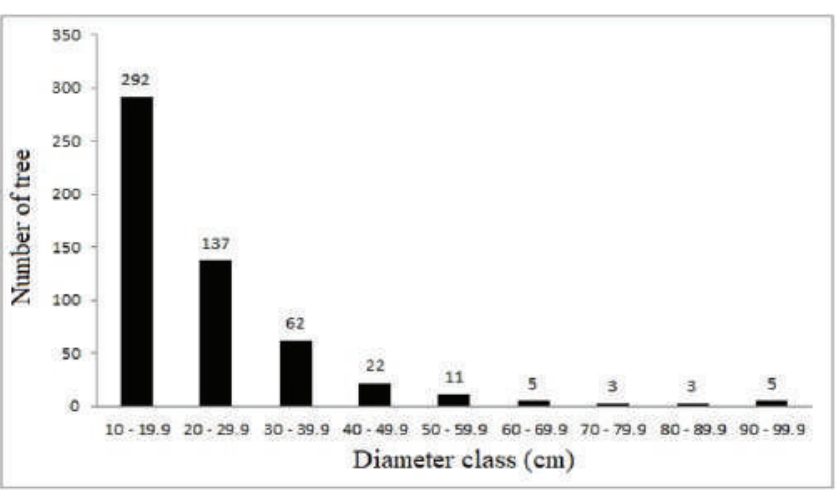

Figure 3. Species-area curve of tree species with $\mathrm{DBH} \geq 10$ $\mathrm{cm}$ in 100 subplots of the $100 \mathrm{~m} \times 100 \mathrm{~m}$ plot in the forest of the midsection of BDNP core zone.
Four height classes of trees in the plot could be identifed (Figure 5), comprising the A stratum $(>30$ m), B stratum (20.1-30 m), C stratum (4.1-20 m) and D stratum (1.1-4 m) The highest number of trees (452) occurred in the 4-20 m class (Figure 5). The A stratum which was the emergent stratum was dominated by Dipterocarpaceae, the $\mathrm{B}$ stratum by Moraceae, Burseraceae and Flacourtiaceae, the $\mathrm{G}$ stratum by Burseraceae, and the $\mathrm{D}$ stratum by the four families, each of which was represented by one tree.

Figure 6 is a simulated profile diagram of the forest on the plot constructed using the method of Kartawinata et al., (2004) by plotting each tree sequentially during the recording and measuring the

Table 4. Number of trees of 10 species with highest importance values (IV) along the diameter class gradient in a one-hectare plot in the forest of the midsection of the BNDP core zone, Jambi.

\begin{tabular}{|c|c|c|c|c|c|c|c|c|c|c|}
\hline \multirow[b]{2}{*}{ No } & \multirow[b]{2}{*}{ Species } & \multicolumn{9}{|c|}{ Diameter class $(\mathrm{cm})$} \\
\hline & & $\begin{array}{l}10- \\
19.9\end{array}$ & $\begin{array}{l}20- \\
20.9\end{array}$ & $\begin{array}{l}30- \\
30.9\end{array}$ & $\begin{array}{l}40- \\
40.9\end{array}$ & $\begin{array}{l}50- \\
50.9\end{array}$ & $\begin{array}{l}60- \\
60.9 \\
\end{array}$ & $\begin{array}{l}70- \\
70.9\end{array}$ & $\begin{array}{l}80- \\
80.9\end{array}$ & $\begin{array}{l}90- \\
90.9 \\
\end{array}$ \\
\hline 1 & Dacryodes rostrata & 22 & 4 & 4 & 2 & & & & & \\
\hline 2 & Shorea leprosula & 6 & 2 & 2 & 3 & 3 & & 2 & 1 & \\
\hline 3 & Hydnocarpus sp. & 14 & 11 & 4 & 1 & 2 & & & & \\
\hline 4 & Antidesma neurocarpum & 18 & 7 & 5 & & & & & & \\
\hline 5 & Dialium platysepalum & 4 & 0 & 2 & 2 & & & & 1 & 2 \\
\hline 6 & Artocarpus odoratissimus & 2 & 5 & 2 & 3 & 1 & & & 1 & \\
\hline 7 & Dacryodes rugosa & 15 & 6 & 1 & & & & & & \\
\hline 8 & Parashorea lucida & 4 & 3 & 1 & & 2 & 1 & & & 1 \\
\hline 9 & Mussaenda frondosa & 6 & 8 & 3 & & & 1 & & & \\
\hline 10 & Symplocos sp. & 6 & 7 & 3 & 1 & & & & & \\
\hline
\end{tabular}

trees. It revealed the heights of the individual trees from $1.9 \mathrm{~m}$ to $45 \mathrm{~m}$, forming the A, B, C and D strata. The heights of the strata in BDNP were shorter than in the undisturbed primary forest at the Batang Gadis National Park, where the A stratum was 50-60 m and the $\mathrm{B}$ stratum, which was the main forest canopy, was 30-50 m. The tallest tree with the height of $45 \mathrm{~m}$ and $\mathrm{DBH}$ of $86 \mathrm{~cm}$ was Artocarpus odoratissimus. The shortest trees with the height of 1-4 m were Bombax anceps, Memecylon excelsum, Pertusadina eurhyncha and Madhuca sp. with mean DBH of $12.02 \mathrm{~cm}$.

The emergent top A stratum ( $>30 \mathrm{~m}$ ) consisted of only of 16 trees of the 10 prevalent spesies, which were dominated by species of Dipterocarpaceae consisted of five trees or $31,3 \%$ of the total. Dominance of Dipterocarpaceae in the upper canopy is a general characteristics the forests in Sumatra (Anwar et al., 1984; Kartawinata et al., 2004). The B stratum was dominated by big trees, including Artocarpus odoratissimus (mean DBH of $36.74 \mathrm{~cm}$ ), Dacryodes rostrata (mean DBH of $20.02 \mathrm{~cm}$ ), Diallium platysepalum (mean $\mathrm{DBH}$ of $45.17 \mathrm{~cm}$ ) and Shorea leprosula (mean DBH of $38.20 \mathrm{~cm})$. In C \& D strata $(1-20 \mathrm{~m})$ the trees were dominated by species of Burseraceae (12,1\%), Phyllanthaceae (7,0\%), Flacourtiaceae (6,8\%), Lauraceae

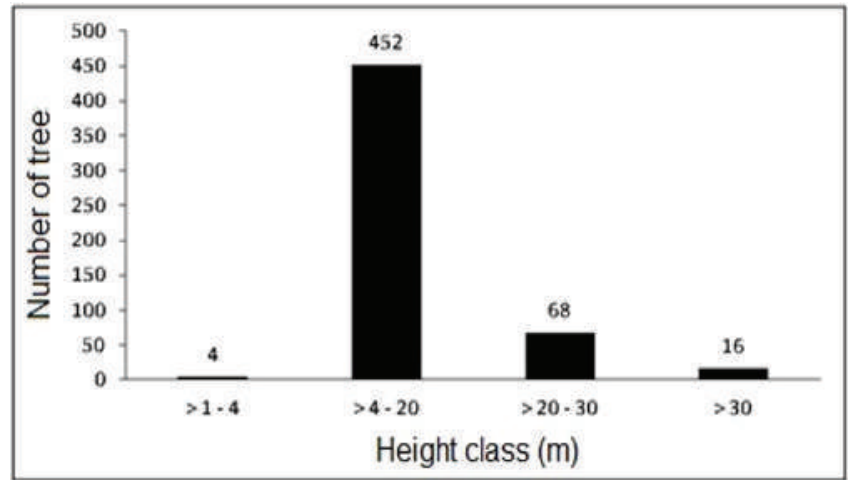

Figure 5. histogram of height class distribbution of trees with $\mathrm{DBH} \geq 10 \mathrm{~m}$ in a one-hectare plot in the forest of the midsection of the BNDP core zone, Jambi.

$(6,6 \%)$ and Dipterocarpaceae $(5,3 \%)$. The $\mathrm{B}$ stratum 20.1-30 m) was dominated by species of the families Moraceae (13,2\%), Burseraceae (11,8\%), Dipterocarpaceae $(10,3 \%)$ and Flacourtiaceae (10,3\%). 


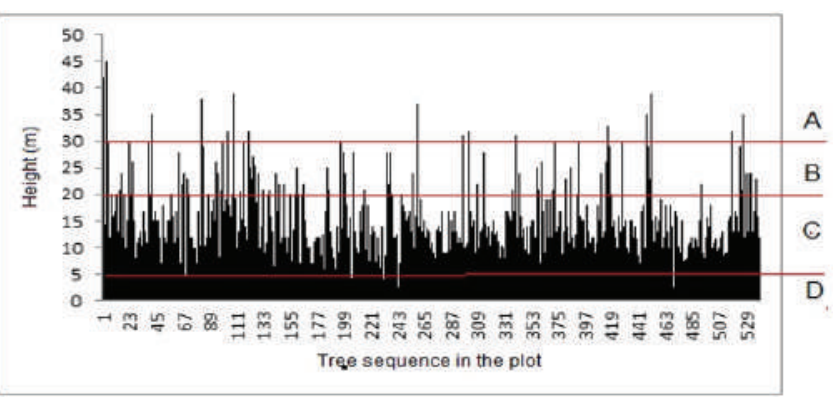

Figure 6. Simulated profile diagram of the forest on the plot constructed by plotting the height of each tree and sequential tree position from tree no. 1 in the $1^{\text {st }}$ subplot up to the tree no 529 in the $100^{\text {th }}$ subplot in the mid-section of the BDNP core zone.

\section{Abiotic Factor}

The topography of the one-hectare study plot is indicatred in Figure 7. The forest in the study site was the lowland primary forest with topography ranging from undulating to hilly. The altitude ranges from 265 $\mathrm{m}$ to $327 \mathrm{~m}$ asl, with slopes vary from 2 to $45 \%$.

The soil had $\mathrm{pH}$ of 5.6-7.36, mean daily temperature was $26.630 \mathrm{C}$, and the relative humidity ranged from $60.3 \%$ to $88.5 \%$.

We recorded that the highest number of trees was recorded at the altitude of $290-299 \mathrm{~m}$ asl (193 trees) and the lowest number at $330-339 \mathrm{~m}$ asl (3 trees). The highest nunber of trees (371) occurred at the slopes of $0-8 \%$ and the lowest number (46) at the slope of 16-45\%. It was comparable to the situatioin in Mt. Galunggung (Pratiwi, 1989) and in the Mt. Gede-Pangranago National Park (Siagian, 2000).

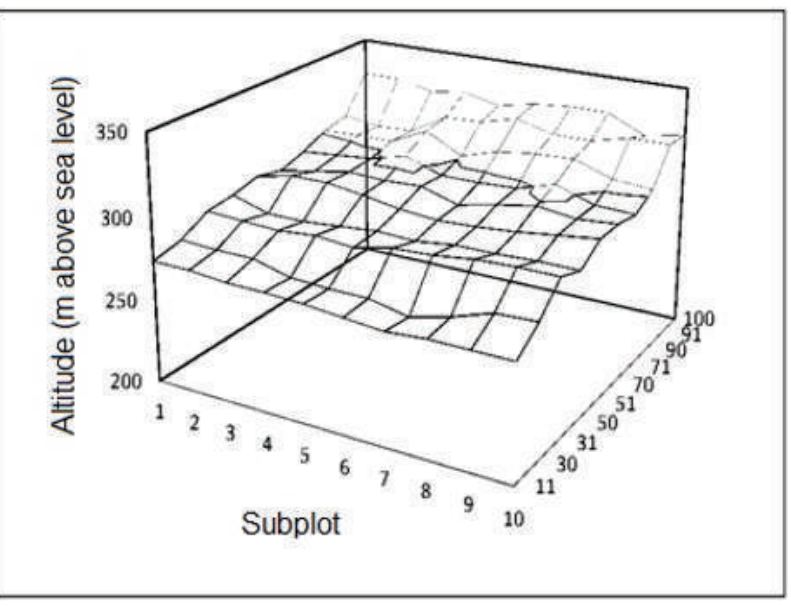

Figure 7. Topographic configuration of the $(10 \mathrm{mx} 10 \mathrm{~m})$ subplots in relation to the one-hectare $(100 \mathrm{~m}$ x $100 \mathrm{~m})$ study plot at the mid-section of the BDNP core zone, Jambi.

\section{DISCUSSION}

Figure 8 shows the comparison of the species richness and the tree density in one-hectare plot in the present study to the findings in one-hectare plots of other studies in lowland forests of Sumatra and Kalimantan. The species richness refers to "the number of species in a sampling unit" (McCune \& Grace, 2002), which indicates species diversity at the first level or alpha diversity (Whittaker, 1972). In the present study the species richness was the lowest amounted to only 89 species per hectare, comparable to those at the research plots in Sarolangun, Jambi (Elviqar, 2013; Hermawan, 2013; Sehati, 2013 and Rahmah et al., 2016). It was much smaller than the species richness in the typical undisturbed primary lowland forests at the Batang Gadis National Park in North Sumatra (Kartawinata et al., 2004) and at Malinau in East Kalimantan (Sheil et al., 2010) with the nunber of 205 species, respectively.

The implication of this phenomenon points to the conditions of the forests in the present study as well as in the other studies in Sarolangun, Jambi (Elviqar, 2013; Hermawan, 2013; Sehati, 2013 and Rahmah et al., 2016). They must have been, in one way or another, diturbed by human activities, including highly destructive selective logging by commercial forest concessionairs and less destructive harvesting by the indigenous Suku Anak Dalam (SAD). As indicated by Sriyanto et al., (2003) the forests at BDNP had a total consisted of primary and secondary forests, which were converted from the permanent production forests, limited production forests and forest designated for other uses. It should be noted that the forests constituting the national park were set aside for the protection of the livelihood of of the SAD inhabiting the natural ecosystems of the area.

The floristic similarity between the present study plot and that in the eastern core zone of BDNP (Rahmah et al., 2016) was $40.8 \%$ and with those at Hutan Adat Imbo Mengkadai (HAIM) 1 and HAIM 2 was $8.3 \%$, respectively, while with the Batang Gadis NP was $5.9 \%$, thus showing a totally different composition. It implies that differences were due to disturbances, leading to diverse compositional development of the disturbed forests resulting from the close assotiation of the regrowth of original forest tree species and the late successional secondary forest species (Connel, 1978; Slik et al., 2008; Sheil \& Burslem, 2003;).

The two dominant species in the plot, Dacryodes rostrata and Shorea leprosula (Appendix 1) signified the secondary nature of the forest. Yusuf (2005) noted that in West Sumatra Dacryoisdes rostrata occurred only in 20-30 years old secondary forests and was not found in 10 years old secondary forest. Secondary forest species recorded in the present study plot included Cratoxylum cochinchinense, Macaranga hypoleuca, Macaranga tanarius, Mallotus mollissimus, Mussaenda frondosa, Neonauclea calycina and Shorea leprosula. Shorea leprosula is a primary lowland rain forest species but often behaves like secondary forest species or even like a pioneer species invading canopy gaps and forest edges (Whitmore, 1986). 


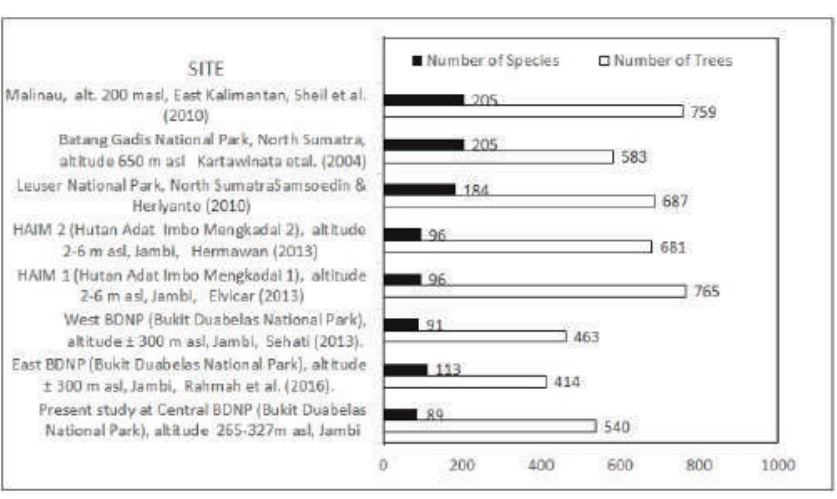

Figure 8. Comparison of the number of species and number of of trees in one-hectare plots in forests of Sumatra and Kalimantan reported in various studies and the present investigation.

The presence of only three species of Dipterocarpaceae with $\mathrm{D}$ (density) of 36 trees/ha and BA (basal area) of $5.01 \mathrm{~m}^{2}$ was unusual in view of the fact that in undisturbed lowland forests of Sumatra, the species of Dipterocarpaceae are generally dominant. It was exemplified by the lowland forest at the Batang Gadis National Park, which contained 16 dipterocarp species with $\mathrm{D}$ of 122 trees/ha and BA of $18.99 \mathrm{~m}^{2}$ (Kartawinata et al., 2004). We assumed that this phenomenon was due to intensive selective logging of dipterocarp species which mostly have high commercial values. The heights of the strata in BDNP (Figure 6) were shorter than in the undisturbed primary forest at the Batang Gadis National Park, where the A stratum was $50-60 \mathrm{~m}$ and the the $\mathrm{B}$ stratum, which was the main forest canopy was $30-50$ $\mathrm{m}$. Structurally it points to the disturbed condition of the forest at the midsection of the core zone of BDNP.

The widespread distribution of Dacryides rostrata as shown by high frequency value of $28 \%$ was apparently related to its fruits, which were palatable to birds and primates (Balgooy, 1998), thus functioned as dispersers. Fruits of Dacryodes rostrata were reported to have high nutritive values, where $100 \mathrm{~g}$ of fruits contained $241 \mathrm{kcal}$ energy, $35 \mathrm{mg}$ protein, $399 \mathrm{mg} \mathrm{K}$, $83 \mathrm{mg} \mathrm{Ca}$ and $83 \mathrm{mg} \mathrm{Mg}$ (Hoe \& Siong, 1999).

Distribution of a species is generally not dependent on the distribution of other species, implying the absence of association among species. It was revealed by the association of species having frequencies $>5 \%$ , indicating the Jaccard Coefficient of $<0.4$ (Figure 9). It was further confirmed by $\mathrm{X}^{2}$ test $(\mathrm{df}=1$ and $a=$ $0.05)$ for 5 species with highest frequency, which showed negative association $\left(\mathrm{X}^{2}<\mathrm{X}^{2}\right.$ Table $)$.

In the plot, we recorded only two species that were listed in the IUCN Red List of having high IUCN conservation status. They were Parashorea lucida and Shorea leprosula. Parashorea lucida had only 12 trees and was listed in the category of Critically Endangered, while Shorea leprosula had only 19 trees and listed in the category of Endangered (Table 5). The entire area of

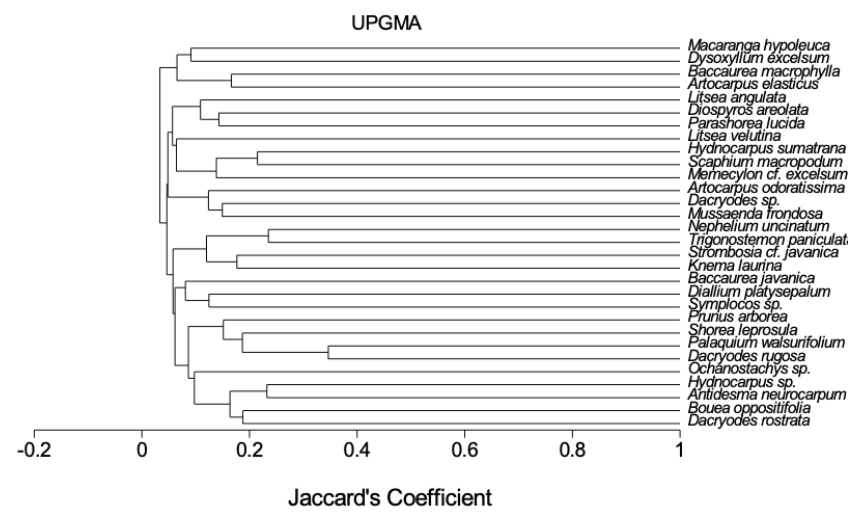

Figure 9. Association dendrogram of species having frequency $>5 \%$.

Table 5. The status of tree species occurring in the mid-section of the core zone of the BDNP as listed in the IUCN Red List Spesies.

\begin{tabular}{|l|l|l|l|c|c|c|c|}
\hline No & \multicolumn{1}{|c|}{ Scientific name } & \multicolumn{1}{|c|}{ Family } & $\begin{array}{c}\text { IUCN } \\
\text { Status }\end{array}$ & D & F & Do & IV \\
\hline 1 & Parashorea lucida & Dipterocarpaceae & CE & 12 & 10 & 1.79 & 10.11 \\
\hline 2 & Shorea leprosula & Dipterocarpaceae & E & 19 & 14 & 2.83 & 15.58 \\
\hline 3 & Dacryodes rostrata & Burseraceae & LR/LC & 32 & 28 & 1.26 & 15.80 \\
\hline 4 & Prunus grisea & Rosaceae & LR/LG & 17 & 16 & 0.70 & 8.72 \\
\hline 5 & Scaphium macropodum & Malvaceae & LR/LC & 10 & 9 & 0.63 & 5.75 \\
\hline 6 & Diospyros areolata & Ebenaceae & LR/LG & 7 & 6 & 0.18 & 3.12 \\
\hline 7 & Aglaia odoratissima & Meliaceae & LR/LC & 6 & 5 & 0.19 & 2.75 \\
\hline 8 & Knema latifolia & Myristicaceae & LR/LG & 4 & 4 & 0.13 & 1.98 \\
\hline 9 & Alangium javanicum & Cornaceae & LR/LC & 1 & 1 & 0.01 & 0.43 \\
\hline
\end{tabular}

Legend: $\mathrm{CE}=$ Critically Endangered; $\mathrm{E}=$ Endangered; LR/LG = Lower Risk/Least Concern

BDNP, however, contained also rare plant species, including Eusideroxylon zwageri, Fagraea fragrans, Calamus manan, Daemonorops draco and Dyera costulata (Kementerian Kehutanan dan Balai TNBD, 2011; Rahmah et al., 2016).

The concept of Hubbell \& Foster (1986) states that if on the average, a species had one or fewer individuals per hectare, it can be considered as a rare species on the local scale. Applying this concept, 59 species of 32 families occurring in the plot can be considered as rare in view of the fact that they had the percentage of number of trees of $1-5 \%$. Of 32 families, 15 of them were represented by one individual each (Table 5). This phenomenon should not be in any way perceived on the global scale as defined by IUCN criteria of rareness.

\section{GONGLUSION}

The one-hectare study plot contained 540 trees, comprising 89 species and 36 families. On the basis of two dominant species we designated the tree community in the forest as the Dacryodes rostrata-Shorea leprosula Association. Folristically it was a poor community with low species richness and non-dipterocarp species were prevalent. The one hectare plot should not in any way considered as the minimal area representing the surrounding forests, but it sufficiently provided an illustration of the forest locally. The plot was established as a permanent plot so that it can be used for monitoring dynamic processes 
and future studies in various aspects valuable to support sustainable management of the BDNP and the livelihood of SAD.

Structurally and floristically the forest represented a developing and regenerating disturbed forest, with heterogenous species composition as reflected by very low frequency and density in the majority of the species. The core zone of the BDNP has undergone changes from dipterocarp dominated forest to that dominated by non-dipterocarps, due to human activities.

A natural succession has been taking place in the forest of the core zone, leading to the formation of forest similar to the original one prior to disturbance. This rate of natural succession is, however, extremly slow. It can be enhanced and assisted by means of ecological restoration through planting of tree species characteristics of forests in Jambi. They include species of Dipterorocapaceae, useful species having values to maintain the livelihood of the SAD, rare and endemic species and others with high conservation values. Species that were persistent and would maintain themselves in the forest in the future are currently represented in almost all diameter classes, although with low density.

\section{AGKNOWLEDGEMENTS}

We are very grateful to the Head of the Education Agency of the Jambi Province and the Regent of Bungo, who provided financial support to the first author (AA) that made the present study possible. Our thanks go also to Ms. Rahmah and Ms. Sehati, the graduate students of the Borany Department of the University of Indonesia, for their assistance and collaboration extended during the field data collection. We thank also the Head and the staff members of the Bukit Duabelas National Park for the permit and for providing various facilities during the field work and allowing to use the map of the Park.

\section{REFERENGES}

Abdulhadi, R. (1991). A Meliaceae forest in Ketambe, G. Leuser National Park, Sumatra, Indonesia. In: Proceedings of the 4th Round-Table Conference on Dipterocarps, Bogor, Indonesia, 12-15 December 1989 (eds: I. Soerianegara, S. S.Tjitrosomo, R. C. Umaly \& I. Umboh), pp. 307-315. BIOTROP Special Publication 41, SEAMEO-BIOTROP, Bogor, Indonesia.

Anwar, J., Damanik, S.J., Hisyam, N. \& Whitten, A.J. (1984). Ekologi Ekosistem Sumatera, Gadjah Mada University Press. Yogyakarta, Indonesia.
BPS (Badan Pusat Statistik) Kabupaten Sarolangun. (2015). Jumlah Curah Hujan dan Banyaknya Hari Hujan Menurut Bulan di Kabupaten Sarolangun Tahun 2015 (Sarolangunkab.bps.go.id . 2015/12, accessed 06 December 2020).

BAPPENAS (Badan Perencanaan Pembangunan Nasional). (2003). Strategi dan Rencana Aksi Keanekaragaman Hayati Indonesia 2003-2020. IBSAP dokumen Regional. BAPPENAS. Jakarta, Indonesia.

Balgooy, M.M.J.van. (1998). Malesian Seed Plants. Backhuys Publisher Leiden.

Berlage, H.P. (1949). Regenval in Indonesië (Rainfalll in Indonesia). Meteorologische en Geophysische Dienst. Koninklijk Magnetisch en Meteorologisch Observatorium te Batavia. Verhandelingen No.37:134.

Connell, J.H. (1978). Diversity in tropical rain forests and coral reefs - high diversity of trees and corals is maintained only in a non-equilibrium state. Science 199: 1302-1310.

Cox, W.G. (1967). Laboratory Manual of General Ecology. WM.C. Brown Company Publisher, Dubuque, U.S.A.

Elviqar. (2013). Komunitas pohon di Hutan Adat Imbo Mengkadai, Desa Temenggung, Kabupaten Sarolangun, Provinsi Jambi. M.Sc thesis, Universitas Indonesia, Depok, Indonesia.

Gillison, A.N. (2001). Vegetation Survey and Habitat Assessment of the Tesso Nilo Forest Complex; Pekanbaru, Riau Province, Sumatra, Indonesia. Report prepared for WWF-US. (October-November, 2001). Cienter for Biodiversity Management, Yungaburra, Australia.

Gillison, A.N., Liswanti, N. \& Ariefrachman, I. (1996). Rapid Ecological Assessment, Kerinci Seblat National Park Buffer Zone, Central Sumatra: Report for Plant Ecology. CIFOR Working Paper No. 14., Bogor, Indonesia.

Harms, K.E., Condit, R., Hubbel, S.P. \& Foster, R.B. (2001). Habitat associations of trees and shrubs in a 50-ha neotropical forest plot. Fournal of Ecology 89: 947-959.

Heriyanto, N.M, Kartawinata, K. \& Samsoedin, I. (2019). Tree species diversity, structural characteristics and carbon stock in a one-hectare plot of the protection forest area in West Lampung Regency, Indonesia. Reinwardtia 18: 1-18.

Hermawan, A. (2013). Komposisi spesies pohon hutan pamah dan keanekaragaman Artocarpus serta pola sebarannya di Hutan Adat Imbo Mengkadai, Kabupaten, Sarolangun, Provinsi Jambi. M.Sc thesis, Universitas Indonesia, Depok, Indonesia.

Hoe, V.B. \& Siong, K.H. (1999). The nutritional value of indigenous fruits and vegetable in Sarawak. Asia Pasific 7.Clin. Nutr 8: 24-31. 
Hubbell, S.P. \& Foster, R.B. (1986). Biology, chance and history and the structure of tropical rain forest tree communities. In: Community Ecology. (eds. Diamond J.M. \& Case T.J), pp. 314-329. Harper and Row, New York, U.S.A.

Kartawinata, K. (2013). Diversitas Ekosistem Alami Indonesia. Yayasan Pustaka Obor Indonesia \& LIPI Press, Jakarta, Indonesia.

Kartawinata, K., Samsoedin, I., Heriyanto, N.M. \& Afriastini, J.J. (2004). A tree species inventory in a one hectar plot at the Batang Gadis National Park. North Sumatera. Indonesia. Reinwardtia 12: 145-157.

Kartawinata. K., Purwaningsih, Partomihardjo, T., Yusuf, R., Abdulhadi, R. \& Riswan, S. (2008). Floristics and structure of a lowland dipterocarp forest at Wanariset Samboja. East Kalimantan. Indonesia. Reinwardtia 12: 301-323.

Kementerian Kehutanan dan Balai TNBD. (2011). Buku Informasi Taman Nasional Bukit Duabelas. Kementerian Kehutanan dan Balai TNBD. Jambi, Indonesia.

Laumonier, Y. (1997). The Vegetation and Physiography of Sumatra. Kluwer Academic Publishers, Dordrecht, Netherlands.

Mansur, M., Triono, T. \& Ismail. (2010). Analisis vegetasi pohon di hutan hujan tropik Harapan, Jambi. Berita Biologi 10: 173-178.

McGune, B. \& Grace, J.B. (2002). Analysis of ecological communities, MJM Software Design, Gleneden Beach, Oregon

Mirmanto, E. (2009). Analisis vegetasi hutan pamah di Pulau Batanta, Raja Ampat, Papua. Jurnal Biologi Indonesia 6: 79-96.

Mueller-Dombois, D. \& Ellenberg, H. (1972). Aims and methods of vegetation ecology. John Willey \& Sons, New York.

Mueller-Dombois, D. \& Ellenberg, H. (2016). Ekologi vegetasi, maksud dan metode, LIPI Press \& Yayasan Pustaka Obor Indonesia, Jakarta, the translated version in Indonesian by Kartawinata, K \& Abdulhadi, R. Aims and methods of vegetation ecology. John Willey \& Sons, New York.

Newman, M.F., Burgess, P.F. \& Whitmore, T.C. (1999). Pedoman Identifikasi pohon-pohon Dipterocarpaceae Sumatera. PROSEA Indonesia, Bogor, Indonesia.

Polosakan, R. (2001). Komposisi jenis pohon di hutan kawasan Taman Nasional Bukit Tigapuluh, Propinsi Riau. In: Proyek Inventarisasi dan Karakterisasi Sumberdaya Hayati (eds.: Sunaryo, Prawiroatmodjo, S., Suyanto, A., Juhaeti, T.,Widodo, W., Napitupulu, R. N. \& Agustiyani, D.), pp. 63-71. Laporan Teknik 2001, Pusat Penelitian Biologi, LIPI, Bogor, Indonesia.
Polosakan, R. (2011). Studi keanekaragaman jenis pohon di kawasan Hutan Danau Bangko, Jambi: analisis aspek ekologi dan pemanfaatannya. In: Valuasi hasil hutan bukan kayu (Kawasan Lindung PT. Wirakarya Sakti Jambi), (eds.: Purwanto,Y., Waluyo, E. B. \& Wahyudi, A), pp. 215-224. LIPI Press, Jakarta, Indonesia.

Pratiwi. (1989). Analisis komposisi vegetasi di areal lahar hasil letusan Gunung Galunggung. Jawa Barat. Buletin Penelitian Hutan 512: 23-31.

Purwaningsih \& Yusuf, R. (2005). Komposisi jenis dan struktur vegetasi hutan di kawasan Pakuli. Taman Nasional Lore Lindu. Sulawesi Tengah. Biodiversitas 6: 123-128.

Purwaningsih, Kartawinata, K., Polosakan, R., Yusuf, R. (2017). Phytosociological study of the montane forest on the south slope of Mt. Wilis, East Java, Indonesia. Reinwardtia 16: 31-45.

Rahmah, Kartawainata, K., Nisyawati, Wardhana, W. \& Nurdin, E. (2016)

Tree species diversity in the lowland forest of the core zone of The Bukit Duabelas National Park, Jambi, Indonesia. Reinwardtia 15: 11-26

Richards, P.W. (1996). The Tropical rain forest; an ecological study. Second Edition, Cambridge University Press, Cambridge, U.K.

Samsoedin, I. \& Heriyanto, N.M. (2010). Struktur dan komposisi hutan pamah bekas tebangan ilegal di kelompok hutan Sei Lepan, Sei Serdang, Taman Nasional Gunung Leuser, Sumatera Utara. Furnal Penelitian Hutan dan Konservasi Alam 7: 299-314.

Sehati. (2013). Komposisi dan struktur hutan pamah di zona inti bagian barat Taman Nasional Bukit Duabelas, Jambi. M.Sc thesis, Universitas Indonesia, Depok., Indonesia.

Setiawan, B. (2010). Kebijakan pembangunan sosial masyarakat adat orang rimba di kawasan Taman Nasional Bukit Duabelas Provinsi Jambi. M.Sc thesis, Universitas Indonesia. Depok, Indonesia.

Setyowati, F.R. (2003). Hubungan keterikatan masyarakat kubu dengan sumber daya tumbuh-tumbuhan di cagar bisofer Bukit Duabelas. Jambi. Biodiversitas 4: 47-54.

Sheil, D. \& Burslem, D.F.R.P. (2003). Disturbing hypotheses in tropical forests. Trends in Ecology E Evolution 18: 18-26.

Sheil, D., Kartawinata, K., Samsoedin, I., Priyadi, H. \& Afriastini, J.J. (2010). The lowland forest tree community in Malinau, Kalimantan (Indonesian Borneo): results from a one-hectare plot. Plant Ecology and Diversity 3: 59-66.

Siagian, R. (2000). Komposisi dan struktur komunitas tumbuhan bawah di areal kebakaran Gunung Masigit dan studi awal regenerasi alami di areal kebakaran Gunung Masigit Taman Nasional Gunung Gede Pangrango. M.Sc thesis, Universitas Indonesia. Depok, Indonesia. 
Silvius, M. J., Simmons, H.W. \& Verheugt, W.J.M. (1984). Soils, vegetation, fauna and nature conservation in Berbak Game Reserve, Sumatra, Indonesia. Research Institute for Nature Management, Arnhem, Netherlands.

Slik, J.W.F., Bernard, G.S., Breman, F.G., Van Beek, M., Salim, A. \& Sheil, D. (2008). Wood density as a conservation tool: quantification of disturbance and identification of conservationpriority areas in tropical forests. Conservation Biology 22: 1299-1308.

Sriyanto, A., Wellesley, S., Suganda, D., Widjanarti, E. \& Sudaryono, D. (2003). Guidebook of 41 National Parks in Indonesia. Ministry of Forestry of Republic of Indonesia, UNESCO and CIFOR, Jakarta, Indonesia.

Steenis, G.G.G.J. van. (1950). The delimitation of Malaysia and its main plant geographic divisions. In: Flora Malesiana Ser. I, Volume I, (eds: Steenis C.G.G.J. van), pp. Ixxi-lxxv. Noordhoff-Kolff, N.V. Djakarta, Indonesia.

Sylviani. (2008). Kajian dampak perubahan fungsi kawasan huttan terhadap masyarakat sekitar. Furnal Penelitian Sosial dan Ekonomi Kehutanan 5: 155-178.

Whitmore, T.G. (1986). Tropical Rain Forest of the Far East. Oxford University Press. Oxford, U.K.
Whittaker, R.H. (1972). Evolution and measurement of species diversity. Taxon 21: 213-251.

Wiriadinata. H. \& Setyowati, F.M. (2000). Kajian pemanfaatan tumbuhan oleh Suku Anak Dalam di Cagar Biosfer Bukit Duabelas Jambi. In: Prosiding Seminar Nasional Ethnobotani III, (eds: Purwanto, Y. \& Walujo, E.B), pp. 274-283. Pusat Penelitian dan Pengembangan Biologi-LIPI, Bogor, Indonesia.

Yamada. I. (1976). Forest ecological studies of the montane forest of Mt. Pangrangoo. West Java III. Litterfall of the tropical montane forest near Cibodas. The Southeast Asian Studies 14: 194-229.

Yusuf, R., Purwaningsih \& Gusman. (2005). Komposisi dan struktur vegetasi Hutan Alam Rimbo Panti. Sumatera Barat. Biodiversitas 6: 266-271.

Yusuf, R. (2005). Keanekaragaman dan potensi jenis tumbuhan hutan sekunder di Kuala Ran. Kabupaten Bulungan. Kalimantan Timur. BioSMART 7: 37-43. 
Appendix 1. Density ( $\mathrm{D}=$ trees/ha), frequency $(\mathrm{F}$ in \%) and BA (Basal Area in $\mathrm{m}$ sq.) of tree species in a one-hectare plot of a lowland forest at the midsection of the core zone of the Bukit Duabelas National Park, Jambi.

\begin{tabular}{|c|c|c|c|c|c|c|c|}
\hline NO & Scientific name & Family & Local name & $\underset{(\text { trees/ha) }}{\text { D }}$ & $\begin{array}{c}\mathbf{F} \\
(\%)\end{array}$ & $\begin{array}{c}\mathbf{B A} \\
(\mathbf{m} 2)\end{array}$ & $\begin{array}{l}\text { IV } \\
(\%)\end{array}$ \\
\hline 1 & Dacryodes rostrata (Blume) H.J.Lam & Burseraceae & Jagul besak & 32 & 32 & 1.261 & 15.80 \\
\hline 2 & Shorea leprosula Miq. & Dipterocarpaceae & Meranti bungo & 19 & 19 & 2.829 & 15.58 \\
\hline 3 & Hydnocarpus sp. & Flacourtiaceae & Kelat merah & 31 & 31 & 1.235 & 14.91 \\
\hline 4 & Antidesma neurocarpum Miq. & Phyllanthaceae & Kelat putih & 30 & 3 & 0.978 & 14.30 \\
\hline 5 & Dialium platysepalum Baker & Fabaceae & Keranji umbut & 11 & 11 & 2.580 & 12.67 \\
\hline 6 & Artocarpus odoratissimus Blanco & Moraceae & Terap kangkung & 14 & 14 & 1.840 & 10.83 \\
\hline 7 & Dacryodes rugosa (Blume) H.J.Lam & Burseraceae & $\begin{array}{l}\text { Kedundung } \\
\text { tunjuk }\end{array}$ & 22 & 22 & 0.542 & 10.17 \\
\hline 8 & Parashorea lucida Kurz & Dipterocarpaceae & $\begin{array}{l}\text { Tengkawang } \\
\text { bukit }\end{array}$ & 12 & 12 & 1.795 & 10.11 \\
\hline 9 & Mussaenda frondosa $\mathrm{L}$. & Rubiaceae & Berumbung & 18 & 18 & 1.021 & 9.33 \\
\hline 10 & Symplocos sp. & Symplocaceae & Kayu garam & 17 & 17 & 0.795 & 9.03 \\
\hline 11 & Prunus grisea (Blume ex Müll.Berol.) Kalkman & Rosaceae & Mesuai & 17 & 17 & 0.698 & 8.72 \\
\hline 12 & Palaquium walsurifolium Pierre ex Dubard & Sapotaceae & Balam merah & 17 & 17 & 0.611 & 8.02 \\
\hline 13 & Artocarpus elasticus Reinw. ex Blume & Moraceae & Terap nasi & 15 & 15 & 0.945 & 7.49 \\
\hline 14 & Ochanostachys sp. & Olacaceae & Petaling putih & 11 & 11 & 0.775 & 6.62 \\
\hline 15 & Knema laurina Warb. & Myristicaceae & Menerah & 14 & 14 & 0.311 & 6.29 \\
\hline 16 & Memecylon excelsum Blume & Melastomataceae & Kelat jambu & 14 & 14 & 0.364 & 6.25 \\
\hline 17 & Baccaurea macrophylla (Müll.Arg.) Müll.Arg. & Phyllanthaceae & Medang labu & 7 & 7 & 1.031 & 5.88 \\
\hline 18 & Scaphium macropodum (Miq.) Beumée ex K.Heyne & Malvaceae & Muaro kepayang & 10 & 1 & 0.629 & 5.75 \\
\hline 19 & Trigonostemon sp. & Euphorbiaceae & Banit putih & 13 & 13 & 0.200 & 5.74 \\
\hline 20 & Dacryodes sp. & Burseraceae & Kedundung kedal & 11 & 11 & 0.471 & 5.63 \\
\hline 21 & Hydnocarpus sumatrana Koord. & Flacourtiaceae & Medang seluang & 9 & 9 & 0.611 & 5.30 \\
\hline 22 & Bouea oppositifolia (Roxb.) Adelb. & Anacardiaceae & Temeras & 10 & 1 & 0.194 & 4.55 \\
\hline 23 & Nephelium uncinatum Radlk. & Sapindaceae & Idan tunjuk & 8 & 8 & 0.193 & 3.76 \\
\hline 24 & Litsea angulata Blume & Lauraceae & Medang pawas & 7 & 7 & 0.284 & 3.66 \\
\hline 25 & Litsea velutina (Blume) Hook. $\mathrm{f}$. & Lauraceae & Medang cempako & 7 & 7 & 0.237 & 3.51 \\
\hline 26 & Strombosia javanica Thwaites & Olacaceae & kayu tulang & 7 & 7 & 0.223 & 3.47 \\
\hline 27 & Gluta sp. & Anacardiaceae & Terentang & 2 & 2 & 0.768 & 3.27 \\
\hline 28 & Parashorea sp. & Dipterocarpaceae & Anai baik & 5 & 5 & 0.381 & 3.20 \\
\hline 29 & Ficus elastica Roxb. ex Hornem. & Moraceae & Kayu aro & 2 & 2 & 0.729 & 3.15 \\
\hline 30 & Diospyros areolata King \& Gamble & Ebenaceae & Banit hitam & 7 & 7 & 0.180 & 3.12 \\
\hline 31 & Dysoxylum excelsum Blume & Meliaceae & Jagul tunjuk & 7 & 7 & 0.156 & 3.04 \\
\hline 32 & Macaranga hypoleuca (Rchb.f. \& Zoll.) Müll.Arg. & Euphorbiaceae & Mang & 6 & 6 & 0.192 & 2.97 \\
\hline 33 & Pternandra azurea (DC.) Burkill & Melastomataceae & Kayu ubi & 7 & 7 & 0.177 & 2.90 \\
\hline 34 & Polyalthia sumatrana (Miq.) Kurz & Annonaceae & Balam putih & 3 & 3 & 0.521 & 2.86 \\
\hline 35 & Archidendron bubalinum (Jack) I.C.Nielsen & Fabaceae & Kabau & 5 & 5 & 0.250 & 2.77 \\
\hline 36 & Baccaurea javanica (Blume) Müll.Arg. & Phyllanthaceae & Tungau & 6 & 6 & 0.129 & 2.77 \\
\hline 37 & Aglaia odoratissima Blume & Meliaceae & Idan cuko & 6 & 6 & 0.186 & 2.75 \\
\hline 38 & Madhuca sp. & Sapotaceae & Putat talang & 6 & 6 & 0.181 & 2.73 \\
\hline 39 & Neonauclea calycina (Bartl. ex DC.) Merr. & Rubiaceae & Medang kuning & 5 & 5 & 0.273 & 2.64 \\
\hline 40 & Lithocarpus sundaicus (Blume) Rehder & Fagaceae & Barangan benar & 4 & 4 & 0.390 & 2.63 \\
\hline 41 & Litsea sp. & Lauraceae & Medang kalo & 5 & 5 & 0.181 & 2.55 \\
\hline 42 & Durio oxleyanus Griff. & Bombacaceae & Barangan babi & 5 & 5 & 0.177 & 2.53 \\
\hline 43 & Neolitsea cassïfolia Merr. & Lauraceae & Medang so & 3 & 3 & 0.342 & 2.28 \\
\hline 44 & Gonocaryum gracile Miq. & $\begin{array}{l}\text { Cardiopteridacea } \\
\mathrm{e}\end{array}$ & Meribung & 4 & 4 & 0.171 & 2.12 \\
\hline 45 & Sterculia cordata Blume & Malvaceae & Kelumpang batu & 4 & 4 & 0.142 & 2.03 \\
\hline 46 & Claoxylon longifolium (Blume) Endl. ex Hassk. & Euphorbiaceae & Medang pangkat & 2 & 2 & 0.371 & 1.99 \\
\hline 47 & Knema latifolia Warb. & Myristicaceae & Cemunik & 4 & 4 & 0.129 & 1.98 \\
\hline 48 & Gordonia excelsa (Blume) Blume & Theaceae & Kayu bulan & 2 & 2 & 0.298 & 1.75 \\
\hline 49 & Diospyros curranï Merr. & Ebenaceae & Kayu cingkuk & 3 & 3 & 0.136 & 1.62 \\
\hline 50 & Cryptocarya crassinervia Miq. & Lauraceae & Medang batu & 3 & 3 & 0.087 & 1.46 \\
\hline 51 & Palaquium ridleyi King \& Gamble & Sapotaceae & Pinang baik & 3 & 3 & 0.080 & 1.43 \\
\hline 52 & Callophylum tetrapterum & Clusiaceae & Selancar & 3 & 3 & 0.074 & 1.42 \\
\hline 53 & Sterculia rubiginosa Zoll. ex Miq. & Malvaceae & Semasam & 3 & 3 & 0.072 & 1.41 \\
\hline 54 & Durio zibethinus L. & Bombacaceae & Durian mas & 2 & 2 & 0.189 & 1.19 \\
\hline 55 & Neouvaria sp. & Annonaceae & kalintang tanggo & 2 & 2 & 0.103 & 1.12 \\
\hline 56 & Madhuca sericea (Miq.) S.Moore & Sapotaceae & Putat tasik & 1 & 1 & 0.219 & 1.10 \\
\hline 57 & Lithocarpus encleisocarpus (Korth.) A.Camus & Fagaceae & Cemening babi & 2 & 2 & 0.042 & 0.92 \\
\hline 58 & Artocarpus anisophyllus Mig. & Moraceae & Berkil & 2 & 2 & 0.036 & 0.90 \\
\hline 59 & Elaeocarpus glaber Blume & Elaeocarpaceae & Keniti & 2 & 2 & 0.030 & 0.88 \\
\hline
\end{tabular}




\begin{tabular}{|c|c|c|c|c|c|c|c|}
\hline 60 & Dialium indum $\mathrm{L}$. & Fabaceae & Keranji batu & 2 & 2 & 0.028 & 0.87 \\
\hline 61 & Macaranga tanarius (L.) Müll.Arg. & Euphorbiaceae & Sengkubung & 1 & 1 & 0.096 & 0.70 \\
\hline 62 & Knema globularia (Lam.) Warb. & Myristicaceae & Anggung & 1 & 1 & 0.064 & 0.60 \\
\hline 63 & Scorodocarpus bormeensis (Baill.) Becc. & Olacaceae & Kulim & 1 & 1 & 0.052 & 0.56 \\
\hline 64 & Nephelium mutabile Blume & Sapindaceae & Samak ketan & 1 & 1 & 0.051 & 0.56 \\
\hline 65 & Gynotroches axillaris Blume & Rhizophoraceae & Kayu buluh & 1 & 1 & 0.045 & 0.54 \\
\hline 66 & Mallotus mollissimus (Geiseler) Airy Shaw & Euphorbiaceae & Setarak & 1 & 1 & 0.044 & 0.53 \\
\hline 67 & Oncosperma horridum (Griff.) Scheff. & Arecaceaae & Bayas & 1 & 1 & 0.039 & 0.52 \\
\hline 68 & Diospyros hermaphroditica (Zoll.) Bakh. ex Steenis & Ebenaceae & Nilau nasi & 1 & 1 & 0.029 & 0.49 \\
\hline 69 & Garcinia parvifolia (Miq.) Miq. & Clusiaceae & Kandih burung & 1 & 1 & 0.023 & 0.48 \\
\hline 70 & Dysoxylum sp. & Meliaceae & $\begin{array}{l}\text { Tampoi kuro- } \\
\text { kuro }\end{array}$ & 1 & 1 & 0.023 & 0.47 \\
\hline 71 & Syzygium cymosum (Lam.) DG. & Myrtaceae & Kelat samak & 1 & 1 & 0.022 & 0.46 \\
\hline 72 & Eurycoma longifolia Jack & Simaroubaceae & Semedu tanah & 1 & 1 & 0.021 & 0.46 \\
\hline 73 & Knema mandaharan Warb. & Myristicaceae & Benal & 1 & 1 & 0.020 & 0.46 \\
\hline 74 & Timonius timon (Spreng.) Merr. & Rubiaceae & Itam telutuk & 1 & 1 & 0.020 & 0.46 \\
\hline 75 & Pittosporum moluccanum Miq. & Pittosporaceae & Kalumpang Beras & 1 & 1 & 0.019 & 0.45 \\
\hline 76 & Paranephelium nitidum King & Sapindaceae & Kemangar & 1 & 1 & 0.017 & 0.45 \\
\hline 77 & Garcinia sp. & Clusiaceae & Inggi daro & 1 & 1 & 0.015 & 0.44 \\
\hline 78 & Microcos opaca Burret & Malvaceae & Sesumpit & 1 & 1 & 0.015 & 0.44 \\
\hline 79 & Garcinia atroviridis Griff. ex T.Anderson & Clusiaceae & Asam gelugur & 1 & 1 & 0.013 & 0.43 \\
\hline 80 & Cratoxylum cochinchinense (Lour.) Blume & Hypericaceae & Semampat & 1 & 1 & 0.013 & 0.43 \\
\hline 81 & Bombax anceps Pierre & Malvaceae & Kakabu & 1 & 1 & 0.013 & 0.43 \\
\hline 82 & Memecylon edule Roxb. & Melastomataceae & Belimbing hutan & 1 & 1 & 0.013 & 0.43 \\
\hline 83 & Ochanostachys amentacea Mast. & Olacaceae & Petaling merah & 1 & 1 & 0.013 & 0.43 \\
\hline 84 & Gironniera hirta Ridl. & Cannabaceae & Medang sailok & 1 & 1 & 0.011 & 0.43 \\
\hline 85 & Pertusadina eurhyncha (Miq.) Ridsdale & Rubiaceae & Kayu pisang & 1 & 1 & 0.011 & 0.43 \\
\hline 86 & Neolitsea sp. & Lauraceae & Medang pergam & 1 & 1 & 0.011 & 0.43 \\
\hline 87 & Alangium javanicum (Blume) Wangerin & Cornaceae & Nilau ruso & 1 & 1 & 0.010 & 0.43 \\
\hline 88 & Baccaurea dulcis (Jack) Müll.Arg. & Phyllanthaceae & Tampoi kerawak & 1 & 1 & 0.010 & 0.43 \\
\hline 89 & Unidentified & & Akar jangat & 1 & 1 & 0.032 & 0.49 \\
\hline \multicolumn{4}{|c|}{ Total } & 540 & 540 & 30.837 & 300 \\
\hline
\end{tabular}

